\title{
Political Turmoil in Thailand: Thaksin, Protests, Elections, and the King
}

\author{
by Michael $\mathrm{H}$. Nelson \\ J. Contemp. East. Asia (ISSN 2383-9449) Vol. 5, No. 1, September 2006: 9-25 \\ DOI: http://dx.doi.org/10.17477/jcea.2006.5.1.009 \\ (eastasia.at ISSN 1684-629X)
}

In the concluding section of my preceding assessment of the political situation in Thailand (see eastasia.at, Vol. 4, No. 2, December 2005), I anticipated six months of suspense. Factors assumed to contribute to this suspense were the decision of the Supreme Administrative Court on the privatization of the Electricity Generating Authority of Thailand (EGAT); a disappointing cabinet reshuffle; the second Senate election on 19 April 2006 producing a TRT-dominated Upper House; and a no-confidence debate against a number of ministers for alleged corruption. In reality, the course of political events unexpectedly accelerated. On 24 February 2006, Prime Minister Thaksin Shinawatra dissolved the House of Representatives and called for new elections to be held on 2 April.

\section{From the "Sondhi Phenomenon" to "Thaksin ook pai!"}

After Sondhi Limthongkul-the founder of the newspaper Manager, and since late September 2005 on a self-styled mission to rescue the Thai nation from the clutches of "Thaksinocracy" by calling for a royally-appointed government—on 13 January 2006 led about 3,000 protestors from Lumpini Park to Government House, his star seemed on the wane. A few hundred of Sondhi's followers had forced their way into the compound. Many observers thought that this action went too far. Moreover, it was lamented that Sondhi could not present any new revelations about Thaksin's alleged myriad of serious wrongdoings. Reflecting on the possibility that politically-oriented non-governmental organizations (NGOs) could join Sondhi in what appeared to be a personally motivated retaliation campaign against the prime minister, Thirayuth Boonmee, a leading social critic, said that "activists needed more evidence of corruption to try to bring down the Thaksin government" (The Nation, 15 Jan. 2006). The Nation (20 Jan. 2006) proclaimed that "Mob politics is not the answer," and spoke of the "self-styled Thaksin haters-cum-reformists" with their "less-than-transparent cause." The editorial continued:

It is not inconceivable that a genuine people's movement for political reform can arise from Sondhi's campaign. It is simply a matter of rebalancing the mix: more rationality, less raw emotion, more public education, less incitement.[i]

Since Sondhi's "crusade against Prime Minister Thaksin Shinawatra falters" (Bangkok Post, 22 Jan. 2006), a mass demonstration at Sanam Luang, announced for 4 February, was generally seen as a good way for Sondhi to achieve a "soft landing" (ibid.) of his campaign. He had announced that he would end that event by submitting a petition to the King and then withdraw from organizing any more protests.

In short, Thaksin's political life seemed well on its way to being relieved of some burden. Even this burden should not have been taken as seriously as many observers and political actors did, thus increasing political tension. After all, in a democracy, one should not be too surprised that some people are unhappy with what the government does. Neither should the public demonstration of such dissent be perceived as something unusual in an open political order.[ii] In any case, 
Thaksin himself fanned the flames with the sale of his company, Shin Corporation, for 73 billion baht to the investment holding Temasek, after Shin's share value had tremendously increased since 2001 during Thaksin's time in office. With this transaction, important government concessions for the biggest mobile phone network and the satellite monopoly, a low-cost airline, a television channel, an Internet service provider, a marketing firm, and others in effect became the property of the government of Singapore, which is the owner of Temasek.[iii]

This sale to a foreign government was engineered by a Thai prime minister who had founded his political party on nationalist sentiments, even calling it "Thais love Thai" (Thai Rak Thai, TRT). Matters were made worse by the fact that the sale obviously had been meticulously planned over many months by a number of Thaksin's close legal and management confidents, with the probable aim of avoiding payment of a single baht of tax for this sale.[iv] Hardly any observer was prepared to believe that Thaksin was as surprised by the sale of his own company to Singapore as everybody else. Yet, this had to be his official line of defense because Article 209 of the Thai Constitution stipulates strict separation of executive political power from the pursuit of private business interests. Members of the cabinet must not hold any shares in companies, and they must also not take part in any management decisions.[v] Furthermore, the sale raised the question of whether Thaksin had used the relationship he had built in his capacity as prime minister of Thailand with the prime minister of Singapore for gaining private profit.

Some time later, former prime minister (1980-1988) and highly respected chairperson of the King's Privy Council Prem Tinsulanonda, in a speech on responsible state administration based on the example of the King, voiced the opinion that it was probably not positive to act based only on capabilities and cleverness, without the observance of ethical principles. Although Prem added that these remarks were not directed against anyone in particular, it was a short step to interpret them as criticism of Thaksin's style of governance.[vi] Moreover, conservative legal expert Meechai Ruchuphan, who had helped the government with some law-related work, was quoted in Matichon (13 Feb. 2006) as having said, "This government supports clever people in order to use their cleverness in any way that would make them succeed over their competitors. For this reason, we lack people to whom the protection of the interest of the state and the nation is dear to their hearts." Many people complained that Thaksin had miserably failed in following moral principles. This was used by many well-known personalities for demanding Thaksin's resignation, often by using open letters.

Against this background, the protest demonstration of 4 February gained new importance. More than 50,000 people joined Sondhi in demanding Thaksin's resignation; he also submitted a petition to the King to this effect. Moreover, Sondhi did not withdraw himself from the political arena. On the contrary, he announced yet another show of dissent for 11 February, which attracted a smaller number of people than the previous week. Yet, it was the first time that Sondhi had not treated the event as his personal affair, but acted as a member of the "People's Alliance for Democracy." The PAD, basically Sondhi plus some members of political NGOs, such as the Campaign for Popular Democracy, had been formed on 9 February. This way, the usual collection of activists from the "people's sector" (phak prachachon) entered the fray. The Nation (10 Feb. 2006) indicated a change in its stance concerning the "mob politics" criticized above by the headline "Move to oust Thaksin: Real war has just begun." [vii]

Yet, getting some vocal but powerless members of NGOs to join, and even acquiring the mass media firepower of the Nation Group might not have helped the PAD in its final aim of "Toppling Thaksin."[viii] The decisive addition to this coalition came when Buddhist fundamentalist Chamlong Srimuang, who some years earlier had installed Thaksin as chairperson of his Palang Dharma party, announced on 19 February that he would join PAD. His stated reasons were, first, that Thaksin's sale of his company had made him lose his legitimacy as prime minister. Second, Chamlong's previous boss, Prem, had been attacked on TV (see fn. 6). [ix] It 
remained unclear why Thaksin should resign rather than the two hosts of the incriminated television show. And the sale of his company might have led to demanding the establishment of an investigation commission rather than Thaksin's immediate resignation. Anyway, Chamlong declared that he would lead his "Dharma Army" to join the protests until Thaksin stepped down.

It was not only The Nation (20 Feb.) that saw this announcement as "one of the severest blows" to the prime minister and as a "major boost" for the anti-Thaksin forces. After all, it was Chamlong who had played a vital role in bringing down Prime Minister Suchinda Kraprayoon in May 1992. Thaksin must have had similar thoughts. Five days after Chamlong's announcement, on 24 February, and even before the next big demonstration planned for 26 February, Thaksin dissolved the House of Representatives and ordered new elections to take place on 2 April 2006. In the short term, however, this measure could not save him. Already on 21 February, Chamlong had declared that, "A House dissolution would be out of the question because it could bring Mr. Thaksin back to power" (Bangkok Post, 22 Feb. 2006). As a result, rather than accepting the election as a way of resolving the political conflict by letting the voters decide the fate of Thaksin, on 14 March PAD started beleaguering Government House. The backbone of the demonstrators camping out in front of the seat of government was made up of Chamlong's Dharma Army. In the late afternoons and evenings, they were joined by thousands of lower-class people and tens of thousands of members of Bangkok's middle class, listening to often furious attacks on Thaksin. The technical infrastructure and the communication equipment seemed to have been provided by Sondhi. The demonstrators' battle cry was: "Thaksin ook pai!" - "Thaksin, get out!"

\section{Democracy?}

Apparently, the leaders of the protestors did not want to get involved with constitutional means of removing office holders who stand accused of corruption and abuse of power.[] Perhaps, they assumed that the "Thaksin system" had rendered legally available mechanisms meaningless, or maybe they were merely impatient and saw the alliance of anti-Thaksin forces under the umbrella of PAD, combined with the already achieved degree of public mobilization, as a golden opportunity for getting rid of Thaksin. It is still being discussed whether the PAD's tactics remained within democratic means-backed by the freedom of assembly-or whether they had crossed the line to "mob rule."[xi] Beleaguering the seat of government by setting up tents and blocking roads for weeks certainly substantially infringed on the rights of non-participants in the protests, be it government officials (including the prime minister) or be it members of the public. For making their voices heard, the PAD did not depend on such means, since they could have camped out at Sanam Luang. Nevertheless, the Bangkok Metropolitan Administration provided them with many toilet trucks, while the police, instead of being ordered by the government to dissolve the protests, provided security for them. It would have been difficult not to find it reasonable if the government had insisted on keeping up public order, rather than bowing to the protestors' implicit threat of a violent ending. However, in practical-political terms, any attempt at doing so would have been-sooner or later-the end of the Thaksin government. It was thus in the prime minister's best interest to weather the storm engulfing his official residence.

Some observers asked what the use of votes actually was when only shortly after a convincingly won election tens of thousands of protestors, for some months led by a demagogue with doubtful (until today) motives, could build up so much pressure in the heart of Bangkok that the countrywide electoral legitimacy of the prime minister faced unsolvable problems. In addition, many of the speeches delivered at various venues were not educational, but rather aimed at inciting hatred. In a particularly regrettable case, the leader of a teachers' association in the northeast, of all people, "educated" the audience about Thaksin and his family by saying, "Whoever cheated [the country], may their children become whores infected with venereal disease!" (The Nation, 1 March 2006). This sort of speeches went so far that the chairwomen of Thai Amnesty International felt compelled to send an 
email of caution to the organizers of the protests, reminding them that the "non-violent" means so cherished by the PAD not only concerned the absence of direct physical violence (quoted in The Nation, 1 March 2006):

It would be great if the demonstration leaders tried to control the speakers' language on stage. The way we've condemned Thaksin and his family has been rather rude. Aueychai Watha's words about prostitutes [in regard to Thaksin's daughter] were not proper. Sulak did not have to compare Thaksin to a dog ...I was saddened to hear the speaker call for Thaksin's execution. I myself am strongly against the death penalty, and this is not funny. We do not support violence, and neither should we foster conditions that would provoke violence.[xii]

Generally, Thaksin was portrayed as Satan, intent on destroying the Thai democracy. In one brochure distributed by the protestors around Government House, Thaksin was depicted as a reborn Hitler who forced his fellow citizens to raise their arms to the Nazi salute; as a person kowtowing on a pile of fellow-Thai skulls to US imperialist capitalism; and as offering Thailand on a silver platter to international Jewish (and Chinese) monopoly capitalists.[xiii]

Further, the vast majority of voters living outside of Bangkok and the bigger cities was openly denounced as uneducated, uninformed, open to bribery, and morally deficient. This presumption of a significantly privileged political understanding on the side of the activists and their supporters provided the ideological basis for giving much greater weight to the Bangkok-based anti-Thaksin forces than to Thaksin's rural supporters in deciding the question of legitimacy. On the claim that rural voters were unable to make an informed judgment of Thaksin's corruption, Andrew Walker notes:

This strikes me as an extraordinary claim given that discussions about the appropriateness or inappropriateness of obtaining personal gain from public office appear to be ubiquitous in rural society.[xiv]

In a political-practical respect, the PAD had great organizational advantages compared to the mobilization problems of upcountry dwellers. Universal suffrage might be enshrined in the Thai Constitution. However, until now, it does not seem generally to have been accepted by groups in Bangkok, or it is accepted only as long as they agree with its electoral outcome. The large political gap between urban and rural areas-lamented about for decades-persists. From this perspective, the protests constituted yet another rejection of what is seen by many Bangkokian academics, NGO activists, technocrats, and members of the middle class as the "tyranny of the rural majority." [xv]

However, this "tyranny" has become considerably more direct compared to the time before the 2001 election. Prior to that year, critics of rural voting behavior could direct their attacks to constituency candidates who were said to have gained their MP status by vote-buying in their local area. The prime ministers of Thai coalition governments had no immediate electoral legitimacy, but were only indirectly supported by votes of the constituency MPs who in turn elected them in Parliament to head the government. This fundamentally changed with the introduction of the party-list system by the 1997 Constitution. Thaksin Shinawatra is the first PM who could claim a very convincing direct mandate from the voters to govern the country. This primarily means the rural voters. After the 2005 election, there were no serious voices that would have claimed Thaksin received "his" 19 million votes (Democrats: seven million) on the basis of electoral cheating. Rather, they were seen as a true reflection of the will of the voters. As a consequence, any Bangkok-based actions to topple the PM cannot avoid having to declare that the great majority of votes cast for Thaksin did not have as much weight as that of the comparatively small group of protest organizers, their followers, and their supporters. Thus, the protests very directly confronted the majority of voters, mainly those in rural areas. 
However, the situation is complicated by Thaksin's own actions as head of the government since 2001. Probably only his most diehard supporters wouldwhen given time to carefully reason based on information-still doubt that Thaksin is not a democratic politician and that he has had a fatal impact on Thailand's fledgling democratic and constitutional structures. [xvi] On 19 July 2006, the Bangkok Post quoted Thaksin as having told a meeting of local government politicians:

Difference is beautiful in a democracy. Everybody has his or her own rights. Don't be so self-absorbed. Everybody has to respect one another. Don't regard people outside your own group as enemies.

A few weeks earlier, Thaksin told a meeting of high-ranking civil servants, "I will not allow any changes that don't observe the democratic process. I will protect democracy. Let me repeat I will protect democracy with my life" (Bangkok Post, 30 June 2006). Democracy had already been a TRT theme in the campaign to the elections of 2 April 2006. In July, on the occasion of the $8^{\text {th }}$ anniversary of TRT, full-page newspaper advertisements claimed the party would "adhere to democracy." Unfortunately, since the founding of TRT, democracy had hardly ever been mentioned by Thaksin. On the contrary, he had aimed for "quiet politics" (kanmueang ning) under his centralizing and all-controlling leadership. When activists and academics tried to remind him that he should not negatively impact Thailand's democratic political order and respect the publicly expressed differences of political opinions, he retorted with the famous words, "Democracy is only a tool, not an end."

In short, had Thaksin followed his own words as quoted in the Bangkok Post from the time he first assumed the position of prime minister, he as well as the country would never have gotten into the present political quagmire. Regrettably, all positive references to democracy are merely expressions of pure communicative opportunism.[xvii] Thaksin adopted the democracy rhetoric only when he could use it against his various groups of opponents. Therefore, one should not mistake them as reflecting his stance, or even as a change in his approach to governance. Rather, those observers who have called Thai politics under Thaksin "democratic authoritarianism" remain correct.[xviii] One element of this order is that the prime minister undermines the democratic structures and constitutional institutions at the center of the polity, while the voters on the periphery continue to elect their autocratic ruler based on the benefits his populist policies delivered to them.

Assuming that those who doubt Thaksin's democratic credentials are not merely jealous of his power and do not suffer from hallucinations, but can provide plenty of data in support of their claims, reliance on election results alone would mean that the dismantling of core elements of the democratic order must be permitted. In a democracy, after all, the explicit or implicit political will of the majority-as expressed at the ballot box-determines the direction of politics. If the majority thinks that at this point in time a strong leader is more important than an imperfect democracy, so be it. On the other hand, democracy is supported because it provides, if further developed, a much better deal to the people than a leader-based political order, which is also invariably more susceptible to the abuse of power. Thaksin serves as yet another "good" example of this old insight. Thus, the weakening of democratic structures based on the short-term needs of an authoritarian leader will have negative effects on the overall welfare of the country's people in the medium and long term. Thus the question posed by Chang Noi, "Do we allow a leader to use the democratic process to destroy the democratic process itself?" (The Nation, 3 April 2006). But who is the "we" (or "us") who is supposed to decide the issue, based on what considerations, and who is included in the category logically opposed to the "us", that is, in "them"-Thaksin alone? Can we assume that the main protagonists of the protests-Sonthi Limthongkul and Chamlong Srimuang —in fact are motivated by any love for democracy?

Things are even more complicated by the diversity of issues used to attack Thaksin. From the beginning at Lumpini Park, anti-privatization groups played a 
prominent role. It was them who produced and sold the combined "Thaksin-out-noprivatization" T-shirts in great numbers. Later, further policy issues included anti-Free Trade Agreement and even education reform. Of course, after the sale of Shin Corporation, the issue of the morality of the prime minister became important, especially in adding more moderate groups, such as lecturers from universities, to demand Thaksin's resignation by publishing open letters. Yet, disagreements over policy issues are very common in any democracy. As such, they are suitable for use in policy debates, but surely not for trying to force an elected PM from office. The same applies to the issue of morality. It justifies the issuing of open letters demanding Thaksin's resignation. But it cannot justify mass street protests to force him out. In summary, reducing the anti-Thaksin street protests to the democracyversus-dictatorship dichotomy probably is too simple as an approach for analyzing the events.

Finally, a word on the "democratic" means used by the various groups in pursuing their goals. Both sides seemed to think that applying questionable practices was justified by their noble ends. I already mentioned the beleaguering of Government House by the PAD, and its hate campaign against the prime minister. In addition, they blocked the office building housing the Election Commission (ECT) for many hours. Drivers of cars leaving the building were pressed to open their trunks, because the protestors assumed that Wasana Phoemlarp, the ECT's chairperson, and his fellow commissioners would try to flee the scene this way. In the South, demonstrators hindered candidates in their attempt to register for repeat elections; others were forced to run the gauntlet.

In Chiang Mai, pro-Thaksin groups broke up an election campaign event organized by the Democrat party. In Bangkok, some of the rural counter-protestors camping out at Chatuchak Park went to The Nation building and blocked it. And in Udon Thani, a seminar organized by the PAD was broken up. In all three cases, members and supporters of Thaksin's TRT were obviously instrumental in implementing these actions. All the examples show that Thailand's democratic political culture still seems to be rather fragile. If necessary, pushing through one's political will is not subject to many restrictions.

\section{The "elections" of 2 April 2006}

Since Thaksin had set the new House elections for 2 April, there were only 37 days left until election day. According to the letter of the constitution, this was permitted because, after the dissolution of the House, new elections must take place within 60 days. However, the constitution also stipulates that elections following the end of the term of the House must be held within 45 days. Amongst others, it was conservative jurist Meechai Ruchuphan who, in an article criticizing the ECT (Post Today, 25 April 2006:A9), pointed to the fact that a dissolution was difficult to foresee for the opposition parties, and therefore the constitution gave them more time to prepare in such a case. With some justification, the Democrat, Chart Thai, and Mahachon parties could have felt unfairly treated by Thaksin. After all, he had always maintained that he would never dissolve Parliament. On 22 November 2005, Thaksin assured his ministers: "I confirm that I will not dissolve Parliament or resign because nothing will disrupt [this administration's work] before the election scheduled for April 2009" (The Nation, 22 Nov. 2006). He reiterated this stance in December and January. Of course (and as Thaksin's statement in November shows), before the dissolution finally came, it had been pondered for months as a possible way out for Thaksin, in particular with respect to re-stating the legitimacy of his government.

In an article published two weeks before the actual dissolution, Thitinan Pongsudhirak, a politics lecturer at Chulalongkorn University and political commentator, wrote: "The best way out for Mr. Thaksin and for Thailand's precarious democracy based on the hard-won 1997 Constitution, is for the prime minister to renew his electoral mandate at the polls by dissolving the lower house" (Bangkok Post, 10 Feb. 2006). Indeed, this should be seen as a very obvious option in a situation where a PM, in February 2005, wins a very convincing electoral 
mandate, and then, only seven months later, encounters bizarre and personallymotivated claims by an alienated friend and maverick demagogue that he has lost all legitimacy to govern the country, followed by sections of Bangkok society slowly adopting this view. That Thaksin tried to demonstrate that his leadership was still legitimate by using the usual democratic means of elections should come as little as a surprise as the unwillingness of the protestors to accept the decision of the voters. Thus, they intensified their attempt at forcing Thaksin out of office before he could receive a renewed electoral mandate by using the means of continuous street protests around Government House.

More important for the creation of Thailand's present murky political situation, however, was the indeed surprising and unprecedented decision of the opposition parties to boycott the election.[xix] Immediately after the announcement of the House dissolution, the Democrat party's executive board had a six-hour "heated debate" on whether they should boycott the election or not. While those who wanted the Democrats to participate in the elections argued that the party could be seen as not abiding by democratic principles, the pro-boycott members argued that there was no problem in the relationship between the House and Thaksin. Rather, Thaksin himself was the problem (The Nation, 25 Feb. 2006). [xx] From this perspective, Thaksin's decision was seen as illegitimate: "The election is widely seen as a set-up that would enable Thaksin to whitewash his tainted leadership and the plethora of corruption scandals involving his family and friends" (The Nation, 26 Feb. 2006). Not surprisingly, the PAD hailed the Democrat's pro-boycott decision. Chart Thai and Mahachon joined the Democrats. All three briefly tried to make a deal with Thaksin, offering to trade their boycott against his signature under a pact for a post-electoral political reform process. However, Thaksin rejected this proposal, and so the boycott went ahead, with all the political and legal problems that have resulted from it, even including an intervention by the King.

So it is certainly correct to assign a fair share of the blame for the present situation to the Democrats, Chart Thai, and Mahachon. The dissolution of Parliament by the prime minister was perfectly within his constitutional prerogative. Moreover, as pointed out above, it was a measure that suggested itself given that the attacks called his legitimacy into question. It is probably not accurate to assume that the parties' decision reflected their unwillingness to get a beating at the polls. They were not afraid of their sure defeats in 2001 or 2005. In fact, given the political climate, they could anticipate coming out of the election with a greater number of MPs. Rather, some amongst the Democrats executive board's majority in favor of the boycott might have been carried away by the anti-dissolution discourse at that time, combined with the possibility of portraying their party as being on the "people's side" against the "tyrant" (thorarat) Thaksin. Others might have seen a good chance to get rid of Thaksin by extra-parliamentary, non-electoral means, since neither parliamentary nor electoral means would have allowed their return to power for many years to come, as long as Thaksin remained head of TRT and the government. In any case, if the entire opposition in a parliamentary democracy (even if it is "Thai-style") deliberately undermines a constituent element of this order-elections-then this cannot be done as an ordinary political game. A boycott can only be justified in so far as the severity of the perceived threat to parliamentary democracy-for example, when the election is sure to be so heavily corrupted that it will be largely meaningless and merely serve to justify the power-holder-that no other means of resistance is available. Be this as it may, in order to arrive at a better understanding of the Democrats' decisive discussion, one would certainly be extremely pleased to receive a word-for-word transcript of that meeting.

With the decision by all parliamentary opposition parties to boycott the election, many constituencies had only a single TRT candidate. According to Article 74 of the Election Act, candidates standing alone must receive at least 20 percent of the eligible voters to be elected. Especially in southern provinces, the stronghold of the Democrat party, many TRT candidates could not reach the required number of minimum votes. Countrywide, a great number of people marked the "abstention" box on the ballot paper; the amount of invalid votes was also unusually high. [xxi] Of 
the party-list ballot, 31.1 percent of the voters ticked "abstain," while 5.8 percent of the votes were invalid. For the constituency votes, the figures were 33.1 and 13.3 percent, respectively. As a consequence of the 20 percent rule, dozens of constituencies saw repeat elections. Still, some of the 400 seats for constituency MPs could not be filled. It is here that the probable "real motive" for the Democrats' boycott might be found. The party did not mean to merely stay away from the election and thus let TRT and a few MPs from small parties enjoy life in the House, while they themselves would spend the four-year term in the extra-parliamentary wilderness. Rather they tried to use their stranglehold in southern provinces to prevent the election of the full number of 400 constituency MPs. As a result, the Democrats were be able to block the Parliament from convening (because it needs the full number of MPs) and therefore prevent Thaksin from forming a new government. When the election commission tried to subvert the Democrats' game plan by admitting new candidates as competitors to TRT candidates in the second round of voting, the Democrat party brought lawsuits against the ECT in the Administrative Court and, more importantly, the criminal court (see below).

Thaksin Shinawatra won $16,420,755$ votes on the TRT party list-a majority of 56.5 percent of the valid votes. With a decrease in turnout of two million, TRT lost 2.6 million votes over the 2005 election. At the same time, the party's constituency candidates lost only 1.2 million votes, thereby reducing Thaksin's advantage over his MPs from 2.4 million to a mere one million votes. Due to an adjustment of constituencies in Bangkok, the capital's number of MPs was reduced from 37 to 36 . While TRT won 32 seats in 2005, only nine of its Bangkok candidates managed to gain more votes than there were abstentions in 2006. Altogether, 1,265,877 (2005: 104,304) Bangkok voters abstained, while 1,168,208 voters (2005: 1,541,829) opted for TRT. In 2005, the Democrats received 1,047,496 for their constituency candidates running in Bangkok. Thai Rak Thai's party-list votes were reduced from $1,668,102$ (57.6 percent) to 1,234,5222 (46.9 percent).[xxii] The pressure exerted by the protestors and the election result prompted Thaksin, on 4 April 2006, to go on TV and declare that he would not be a candidate for prime minister in the next government. However, he would remain at the helm of TRT and fulfill his duty as an elected MP.

It was assumed that some of TRT's constituency candidates surpassed the 20 percent minimum vote only for the reason that party executives had hired members of smaller parties to run as competitors. On the urging of the Democrats, the ECT was forced to investigate such cases and, as a result, initiate the dissolution process concerning two of those parties. It was even found out that the ECT official responsible for keeping the commission's database of members of political parties had been bribed with 30,000 baht to change the dates candidates had joined their parties in a way that would comply with the 90-day rule (election candidates must be members of their political parties for at least 90 days before they register their candidacy).

Initially, the ECT was reluctant to act against the TRT, although observers found it strange that the agency would punish parties that were accused of having been hired "by a big party," but would not try and punish that big party as well. However, at the beginning of May 2006, a report by an ECT subcommittee investigating the involvement of TRT was leaked to the press and published. This report stated that high-ranking members of TRT had hired the parties, and it suggested initiating legal proceedings against TRT and Thaksin. After some more delays, ECT chairperson Wasana Phoemlarp, in his capacity as political party registrar, sent the investigation file concerning TRT to the Office of the Attorney General (OAG). After additional prompting, on 22 June Phoemlarp recommended the party's dissolution. Four days later, Phoemlarp sent a file concerning the Democrat party to the OAG, also recommending that it be dissolved. The OAG changed some details of the ECT's suggestions, but submitted its writs to the Constitutional Court on 6 July. The Constitutional Court will hear the cases following the parties 30 August 2006 submission of their written defenses. 
The Constitutional Court can order the dissolution of parties when they have committed wrongdoings as defined in Article 66 of the Political Party Act, mainly for one or more of three reasons:

Article 66

The Constitutional Court may issue an order dissolving a political party which has carried out any of the following:

(1) an act which overthrows the democratic regime of government with the King as Head or an attempt to gain the administrative power of the State by unconstitutional means;

(2) an act which may be adverse to the democratic regime of Government with the King as Head of the State under the Constitution;

(3) an act which may endanger the security of the State, or may be contrary to law or public order or good morals.

It is very difficult to see how hiring smaller parties to field candidates, hiring a small party to accuse TRT of misbehavior, boycotting the election, or promoting the use of the "no vote" box on the ballot paper could be construed as attempts to overthrow democracy or endanger national security, a catch-all clause left over from previous periods of military dictatorships. Political parties are the backbone of representative parliamentary systems. Dissolving them without exceptionally good legal reasons should be impossible.

The Democrat party has been operating for 60 years, and it is the party that most closely resembles democratic parties in the West. Thai Rak Thai has 14 million members and received overwhelming public support. In addition, political parties cannot be held responsible for what individual board members do. It is certainly necessary to punish people who have committed serious wrongdoing. However, this should not affect the party as a collective entity unless it can be proven that the party's leadership in fact endorsed those actions as expressions of the party's will. Thongbai Thongpao, a former political prisoner, caretaker senator, and veteran lawyer who has been active in the field of legal education for decades, [xxiii] commented in his regular Sunday column, "I don't see any act by the five political parties that crossed the line and posed a threat to national security and morality." As for the charge against TRT based on Article 66 (1), Thongbai noted that it will be very difficult to find evidence in support of such a serious charge. "Therefore, contrary to appearances..., the charge probably does the party more good than harm" (all quotes from Bangkok Post, 2 July 2006).

Interestingly, the punishment for charges as serious as those mentioned in Article 66, in addition to dissolution of the political party, seem to be inconsistently light. Article 69 of the Political Party Act stipulates that any person who "used to be a member of the Executive Committee of the dissolved political party shall not form a new political party, be a member of an Executive Committee of a political party nor be a promoter of a new political party" for five years. In other words, people who had just been found guilty of attempting to overthrow democracy and endangering the security of the state itself, can right away (in the event there will be an election) still become MPs, ministers, and even prime minister. They can also reestablish their old parties under the same names, except that they must find nominees who have not been members of the executive board of their previous outfit. A number of political parties newly registered with the ECT are assumed to have been established by close associates of faction chiefs within TRT-just in case.

\section{The King intervenes - the Constitutional Court nullifies the election}

After the election, the House must convene within 30 days. To do so, the full number of 500 members must have been elected. Since dozens of the House of Representatives' 400 seats for constituency MPs could not be filled due to candidates not reaching the minimum 20 percent of eligible voters, and since a second round of voting also failed to achieve the full number, holding the first meeting seemed to be impossible. [xxiv] As a consequence, no new prime minister could have been elected. It was in this context that, on 26 April 2006, the King 
intervened in an unusually direct and strong form. During separate audiences for judges of the Supreme Administrative Court and the Supreme Court at Klai Kangwol Palace in Prachuap Khiri Khan province, the King asked whether the political situation was perhaps messed up to the point that the election might have to be nullified. He put pressure on the courts to do their part to solve the problems by saying

Should the election be nullified? You have the right to say what's appropriate or not. If it's not appropriate, it is not to say the government is not good. But as far as I'm concerned, a one party election is not normal. The one candidate situation is undemocratic. When an election is not democratic, you should look carefully into the administrative issues. I ask you to do the best you can. If you cannot do it, then it should be you who resign, not the government, for failing to do your duty. Carefully review the vows you have made. ... The nation cannot survive if the situation runs contrary to the law. Therefore, I ask you to carefully study whether you can make a point on this issue. If not, you had better resign. You have been tasked with this duty. You are knowledgeable. You must make the country function correctly. [xxv]

Perhaps directed towards Thaksin, the King said, "I don't know who has messed up things this much. But you cannot govern the country in a messed-up manner." Finally, he sternly reprimanded the protestors, whose campaign goal was to have the King appoint a government based on Article 7 of the Constitution and whose battle cry was "Rescue the nation!" by stating

I have suffered a lot. Whatever happens, people call for a royally appointed prime minister, which would not be democracy. If you cite Article 7 of the Constitution, it is an incorrect citation. You cannot cite it. Article 7 has two lines: whatever is not stated by the Constitution should follow traditional practices. But asking for a royally appointed prime minister is undemocratic. It is, pardon me, a mess. It is irrational.... People call to "rescue the nation." Whatever they do, they call [it] "rescue the country." What do you rescue? The country has not sunk yet. We have to prevent it from sinking; we don't have to rescue it. (The Nation, 26 April 2006)

After the King had given his lectures, the presidents of the Supreme Administrative Court, the Supreme Court, and the Constitutional Court (the King had included this court in his appeal) met to consider their next steps. [xxvi] The Constitutional Court then needed only a few days, until 8 May 2006, to declare the election of 4 April null and void. At the same time, it ordered new elections to be held within 60 days of the amendment of the original Royal Decree, though without determining when this amendment had to be done. There were two reasons for nullifying the election. First, the court found that ordering a new election to take place only 37 days after the dissolution of the House, though not in itself a violation of the constitution, had nevertheless led to political problems serious enough to violate the democratic core of the election.

Second, the court found that by turning the polling booths around in a way that the open part would point to the polling station committee and the public, while the voter would turn his back to both, the constitutionally guaranteed secrecy of the vote had fundamentally been violated. [xxvii] Obviously, one can doubt whether this point really warranted the nullification of an entire election. On the other hand, why would one wish to favor the Thai mai pen rai (never mind) attitude over adherence to the constitution? Moreover, the ECT had already been warned by the Asian Network for Free Elections (Anfrel) in November 2005, on the occasion of some by-elections, that "turning around the open side of voting booths so they could be seen into by outsiders... 'seriously' affected voters' privacy" (Bangkok Post, 5 Nov. 2005). That the constitutionally stipulated secrecy of the vote indeed was seriously compromised could not be doubted.[xxviii] 
Ultimately, however, the court's decision did not so much concern purely legal interpretations, but rather implemented a royally initiated attempt to find a way out of the political "mess" by using the courts and the law. Simply speaking, the question was how one could legally get rid of an election that had politically-not primarily in terms of electoral management by the ECT—been badly screwed up, thereby causing unsolvable political and constitutional problems. The ECT was, so to speak, the "weakest link" in this context. Even under such circumstances, the judges of the Constitutional Court were deeply divided, with only a narrow majority of 8 votes to 6 being in favor of the nullification. One wonders what would have happened if the ECT had not done something that, with a certain degree of justification, could be interpreted as having violated the constitution seriously enough to annul the election. In this sense, people should indeed be grateful to the ECT for what it did.

Not surprisingly, after the verdict the ECT came under strong pressure to resign. For some reason the ECT had come to be seen as untrustworthy in their ability to organize honest and fair elections. The three courts declared their political decision that the ECT had to go. They repeatedly reiterated their stance, showing their impatience after nothing in this direction happened. The courts also declared that they would take over the organization of the election from the ECT, although the constitution gives this task to the ECT. In unison, the press in the capital demanded that the commissioners resign. Finally, one member bowed to the pressure, while his remaining three colleagues stood firm. [xxix] As a result, on 25 July 2006, a criminal court sentenced them to an unsuspended four years in prison for malfeasance in office while managing the April 2006 elections.

In a number of constituencies in the South, where the sole TRT candidates had not achieved the legally required minimum vote of 20 percent of the eligible voters, the ECT had permitted the registration of additional candidates in repeat elections. Such new elections are legally required under the condition just mentioned. The ECT might have seen the permission of additional candidates merely as a method of breaking the 20 percent deadlock, thereby enabling it to conclude the general election within the required 30-day time limit. The criminal court, however, saw this measure as a serious criminal act deliberately designed to advantage certain candidates and/or parties over their competitors. Initially, it was unclear how the ECT could have actively disadvantaged competitors of TRT candidates who were running without any competition. Moreover, the court ruling seemed to imply that new elections would have to be held as many times as it would take to force the electorate to come up with the necessary 20 percent of electoral support.[xxx]

It is still open to question whether the court's ruling represented an instance of the rule of law or merely was yet another case of the rule by law, expressly intended to use the law as a means in order to achieve the declared political end of eliminating the resisting ECT members from the electoral scene. The latter impression was reinforced when the criminal court did not, as is usual, immediately grant them bail, but referred them to the Appeals Court to try their luck. This court also denied their bail application and referred them to the Supreme Court. Since they reached this court after office hours, the ECT members had to spend the night in jail. As a result, they automatically lost their positions, although they also signed their resignation letters while in prison.

This enabled the Supreme Court to assume sole power in selecting 10 candidates-eight of them judges-for the new ECT. [xxxi] For being able to do so, the constitution had to be bent, because any selection of a new set of five election commissioners must be done by both a selection committee and the Supreme Court (Article 138). However, the selection committee could not be established since it also comprises a number of sitting MPs-an impossibility when there is no House of Representatives. While highly regarded legal experts had already identified this problem in May and thus suggested using the existing ECT, three months later an informal agreement amongst the involved parties seemed to have been reached to 
temporarily suspend Article 138 (1) of the Constitution that required the establishment of a selection committee.

On 15 August, the Senate established a special committee to scrutinize the shortlist of candidates sent to it by the Supreme Court. The committee was given 20 days to fulfill its task. Consequently, the new ECT would not be in place on 24 August, the day when the amended Royal Decree ordering the election to be held on 15 October would come into effect. It is therefore probable that the election day will have to be postponed. This would make sense given that the new ECT members will be unfamiliar with organizing elections as well as with the entire electoral structure that starts at the national level and passes through the provincial election commissions and the constituency committees until it reaches the polling station committees. The five people at the top, especially if they have to start administering something as unknown to them as a general election with thousands of staff that they are also not familiar with, will not be able to make much of a difference concerning clean and fair elections at the ground level. For these reasons, some groups-mostly in the anti-Thaksin camp-have suggested postponing the election until December, or even January 2007. Other groups -mostly pro-Thaksin-insist on holding the election on 15 October. After all, the King already signed the Royal Decree.

Whenever the election is held, all those people who unrealistically have come to the conclusion that the ECT was a major pillar in Thaksin's February 2005 election victory are in for a big disappointment.

\section{Outlook}

Soon after the verdict of the Constitutional Court, political activities died down for some weeks in order to celebrate the 60th anniversary of the King's accession to the throne. Thais were given some reprieve from the harsh realities of politics in their country by participating in a prolonged outpouring of worship for their King. Afterwards, rumors of an impending military coup-either in favor or against Thaksin-were spread. Some comments in newspapers appeared to reluctantly consider a coup as a last way out of the political quagmire. Thaksin himself spread the news that the National Intelligence Agency had uncovered that an assassination attempt against him might be undertaken. He also addressed a gathering of hundreds of high-level bureaucrats with a prepared speech telling them that an "extra-constitutional person with a high degree of baramee" wanted to replace him as prime minister by being appointed by the King.[xxxii]

It was immediately speculated that this was a reference to Prem Tinsulanonda, the widely respected former prime minister and present chairperson of the King's Privy Council. Some observers saw this as a challenge of the old elite by a member of the new elite. In fact, Thaksin, with his highly centralistic, semi-presidential and authoritarian "A Country Is My Company" approach[xxxiii] to governing could never really put up with other spheres of influence in the Thai polity, be it the mass media, civil society, the parliamentary opposition, an independent Senate, or independent checks-and-balance institutions under the constitution. Amongst many other activities to control such spheres, he had persistently tried to place confidants in military positions of power to prop up his political stability. Shortly after Thaksin made his remark, Prem addressed 950 Chulachomklao Royal Military Academy cadets, urging them to embrace professionalism. While governments came and went and were oriented to short-term gains, the military's loyalty had to be with the nation and the King, serving long-term goals (The Nation, 15 July 2006). Only a few days afterwards, in another act of defiance, Army Commander-in-Chief General Sonthi Boonyaratglin, replaced scores of middle-ranking officers who were serving under Thaksin's close classmates from the Armed Forces Academies Preparatory School's Class 10, thus weakening their operative capacity in providing Thaksin with army support, should this be needed (The Nation, 20 July 2006). As a journalistic observer of military affairs noted, "the latest military reshuffle serves as an unmistaken message to Mr. Thaksin and his ex-classmates at the pre-cadet school, that Gen Sonthi's first and foremost loyalty is not to them" (Bangkok Post, 
21 July 2006).

In any case, the King finally signed the amended Royal Decree ordering a new election on 15 October 2006. This decree would come into effect on 24 August 2006. In yet another unprecedented demonstration of his political will, the monarch added a handwritten note for the prime minister to the decree. This "Royal Message" (phraratchakrasae) consisted of two points. First, the King signed the Royal Decree because he wanted to see the nation swiftly return to peace and order. Second, the King wanted the election to the House of Representatives to proceed truly orderly, cleanly, and fairly (Matichon, 23 July 2006:13). With the King's signature under the Royal Decree, and especially with his phraratchakrasae, Thailand returned to the political situation when Thaksin dissolved the House on 24 February, the opposition parties declared their election boycott, and Thaksin rejected their last-ditch effort of trading their electoral participation against the contractual promise of constitutional reforms.

However, a number of things have changed. First, the Democrat, Chart Thai, and Mahachon parties can no longer boycott the election. As parliamentary parties, a permanent election boycott is hardly a feasible option anyway. Moreover, the anti-Thaksin climate that might have carried them away in February has largely died down. Finally, the upsurge of royalist enthusiasm since the King's jubilee would not make it seem advisable to appear as acting against the monarch's will, especially since he has clearly expressed what course of action he wants the country to take, and now that he is recuperating in hospital from microsurgery. Chart Thai and Mahachon have kept a very low profile over the past months, while the Democrats have been visible through their anti-corruption activities and by bringing complaints and lawsuits against TRT and the ECT. It remains to be seen how they will design their election campaign-what role policies Thaksin and constitutional reform will play. The Democrats will certainly win the South. It will be interesting to see whether the Bangokians' limited anti-Thaksin vote in April will translate into as many seats for the Democrats in October. The party's prospects in other regions do not seem to be encouraging.

Second, the PAD appears considerably weakened. Compared to previous turnouts, the audiences attending Sonthi's weekly attacks on Thaksin at Lumpini Park have dwindled dramatically. The newspapers seem largely to have stopped paying attention to him. It is difficult to say whether this more generally reflects a decreased mobilization capacity of the PAD. In any case, they have announced that during this time they do not want to cause the King any additional worries, and so they will not organize any mass rallies in the foreseeable future. Obviously, in pursuing its political goals, the PAD must also take into account the public's position concerning the welfare of the King and his political will. Opponents could easily paint the PAD as anti-royalist if they returned to their old ways. After all, it was the King himself who strongly rebuked the PAD (without naming it) in his address to the courts. Moreover, the King, in his "Royal Message", clearly expressed that he wanted to see order return to Thai politics. And it was the PAD itself that had campaigned on a strongly royalist tone. In fact, Sonthi Limthongkul had, from the beginning until today, used the Monarchy as a tool to push for Thaksin's removal, having recently gone as far as calling on the people to decide whether they were on the side of Thaksin or on the side of the King (Phuchatkan, 6 July 2006).

It remains to be seen how the PAD will manage to pursue their aim of forcing Thaksin out of politics without endangering the holding of an honest and fair election. The PAD also lost their parliamentary allies in their quest. Maybe, they could opt for a post-election resumption of their protests in case Thaksin does not follow his earlier announcement to take a political break after the election and thus allow constitutional reform to proceed smoothly. Moreover, it would certainly be positive for political development in Thailand, if the PAD continued its political work upcountry during the election campaign in order to provide the voters with an alternative point of view.

Third, Thaksin Shinawatra has strengthened vis-à-vis his parliamentary 
opponents as well as the PAD. He has also strengthened vis-à-vis any potential opponents within his own party. Before the King signed the Royal Decree, there had been some grumbling against Thaksin within TRT, mainly because the political situation seemed so hopeless. With the political air cleared by the scheduled election, TRT must unite behind Thaksin, because he is both the party's major selling point and its major financier. However, this does not mean that elements dissatisfied with Thaksin's highly centralist approach to TRT and governing would not try to suggest a different path, or perhaps leave the party and government once the election has confirmed Thaksin in his position. So far, Thaksin has not made public his decision whether he would assume the number one spot on TRT's party list and the position of prime minister after TRT's certain election victory. Some assume that he still might take the political break he had announced after the April election, to let constitutional reform run its course. Others speculate that there are concrete signs Thaksin might leave the country altogether for London once the election is over (Matichon, 17 Aug. 2006:11). Given Thaksin's current use of royally inspired reconciliation rhetoric, which almost always includes dressing in yellow (the color of the King), he should certainly take a back seat after the election. However, it is probably not easy to run an election campaign by relying on Thaksin, but at the same time make clear that he will not be the PM of the next government.

As mentioned above, the Constitutional Court has started a case that might lead to the dissolution of five parties, amongst them TRT and the Democrats. In fact, the court's deliberations should not take that long since the legal basis for dissolutions is clear, the case files delivered by the Office of the Attorney General should not pose great challenges in terms of time, and court hearings should not take more than a few days. However, it would be fatal if the court indeed dissolved TRT and the Democrats, as this decision would directly contravene what the King had wished for in his "Royal Message." In addition, the Constitutional Court would create more problems by applying the law instead of using it to solve the political problems, as the King had asked them to do in his appeal preceding the nullification of the April election by the same court. After all, it would remove almost the entire established political class from the political landscape, followed by an election largely without candidates. This might have been the reason why Suchit Bunbongkarn, a former judge at the Constitutional Court, said "the decree could send a signal that the two major parties being tried for alleged electoral fraud would not be dissolved" (Bangkok Post, 22 July 2006). At least not before the election, one might add. The decision could be made after the election, which would allow the political class to remain in politics, because it already would have been returned to the House. Members of Parliament would merely have to join other political parties.

\section{Endnotes}

[i] Ironically, The Nation later became the most emotional, even militant, Pravda-style standard bearer in the protestors' relentless hate campaign against Thaksin. More generally, the protests as reflected in the development of newspaper reporting during the course of events, both in the Thai and English language Thai press, should be a good research object for students interested in the role of a pluralist press (or its absence) in a democracy.

[ii] In the Thai context, however, public demonstrations of this kind, even if they only draw 20,000-40,000 people, such as in the case of Sondhi, are easily placed in the context of the successful anti-government protests of October 1973 and May 1992, including the specter of bloodshed.

[iii] Reportedly, the mood has turned sour in Singapore, because the shares they bought by now have lost about 35 percent of their value. That Lee Kwan Yew criticized the Thai political system might have to do with the fact that Temasek is headed by a lady who happens to be married to his son, who is prime minister of the highly authoritarian city state. 
[v] Thaksin tried to make a joke out of this by saying that it was his kids who did the sale in order to make it possible for him to concentrate on politics. His son, asked about his role in the sale, responded by saying that he did not know a thing, because it was done by the "phuyai" (seniors).

[vi] Two right-wing TV commentators, former Bangkok governor Samak Suntharavej and former appointed senator Dusit Siriwan, both staunch supporters of Thaksin, promptly attacked Prem in their joint show.

[vii] The Nation as such is insignificant, because its readership is tiny. However, the same company also publishes the business daily Krungthep Thurakit and the mass circulation Khom Chat Luek.

[viii] This is the title of an article by Thammasat-based public commentator Kasian Tejapira that appeared in the New Left Review 39, May-June 2006, pp. 5-37. For a journalistic account see Colum Murphy. 2006. “'Thaksin, Get Out!': Why Thais Are Angry.” Far Eastern Economic Review, April 2006, pp. 7-13.

[ix] Of course, some observers speculated that Chamlong had acted on behalf or at least with the encouragement of Prem. The Nation (24 Feb. 2006) reported from a visit Thaksin paid to Prem, that "The premier told a subsequent gathering of top bureaucrats at City Hall that he asked Prem if he had encouraged Chamlong Srimuang to oppose him as allegedly claimed by Chamlong. Thaksin said Chamlong claimed in Nakhon Sawan recently he had decided to join the anti-Thaksin campaign after receiving a supportive phone call from Prem. 'I asked General Prem and he told me that what Maj General Chamlong claimed was untrue. He had never phoned Chamlong. [Prem] insisted he was remaining neutral,' Thaksin was quoted by a source as saying."

$[x]$ Though a group of students at Thammasat University did start the process by collecting 50,000 signatures. Their petition has meanwhile been submitted to the speaker of the Senate.

[xi] On a comparative note, two Southeast Asian countries that are much less democratic than Thailand, at roughly the same time that Bangkok saw mass anti-government demonstrations, made short work of small numbers of demonstrators (Putrajaja) and election campaigners (Singapore). In addition, it is very unlikely that the governments of Australia, Germany, Britain, France or the United States-all undoubtedly democratic-would have allowed such protests to take place.

[xii] This quote is taken from an article written by Subhatra Bhumiprabhas. It was one of only about four pieces printed by The Nation that tried to throw a somewhat critical light on the protests. The hallmark of newspaper reporting during that period was its anti-Thaksin uniformity. Diversity of opinion had largely disappeared.

[xiii] This brochure was "Stop the Thaksin System: Help us Rescue our Nation, Rescue our Democracy" (in Thai). It was produced by Kaewsan Athipho and his twin brother Khwansuang. Kaewsan was a caretaker senator, who, at the time of writing, had been put forward by the Supreme Court as a candidate for the Election Commission of Thailand (ECT), although the constitution requires election commissioners to be of "apparent political impartiality" (Article 136). Khwansuang came in seventh in the Bangkok race to the Senate. Bangkok has 18 senators.

[xiv] From a statement delivered at the Round Table Discussion on Political Crisis in Thailand, held at the National Thai Studies Centre, Australian National University, 23 March 2006.

[xv] Kasian Tejapira. 2005. "Reform and Counter-Reform: Democratization and Its Discontents in Post-May 1992 Thai Politics." In Towards Good Society. Berlin: Heinrich Böll Foundation, pp. 128ff.

[xvi] Not surprisingly, this has become a major point of criticism by Thai and foreign political observers. A useful summary of the issues is found in chapters five and six of Pasuk Phongpaichit and Chris Baker. 2004. Thaksin: The Business of Politics in Thailand. Chiang Mai: Silkworm Books.

[xvii] On the broader issue of "Thaksin's Political Discourse" see chapter five in Duncan McCargo and Ukrist Pathamanand. 2005. The Thaksinization of Thailand. Copenhagen: NIAS Press. 
[xix] I was absolutely stunned when I first read about the boycott. I had never thought that the Democrats, normally seen as bureaucratic, cautious, and legalistic, would be as daring as adopting such a drastic and novel measure with unforeseeable consequences.

[xx] This is a political, not a constitutional argument. Article 116 of the Constitution does not include any reasons for which the House might be dissolved. It stipulates, "The King has the prerogative to dissolve the House of Representatives for a new election of members of the House. The dissolution of the House of Representatives shall be made in the form of a Royal Decree in which the day for a new general election must be fixed within 60 days and this election day must be the same throughout the Kingdom." However, paragraph three of the same article prevents the PM from repeatedly using the dissolution for the same purpose by saying, "The dissolution of the House of Representatives may be made only once under the same circumstance."

[xxi] In the Thai system, voters who want to abstain need to tick the respective box on the ballot paper. Putting the blank paper in the ballot box makes the vote invalid.

[xxii] Figures according to tables in Krungthep Thurakit (5 April, and 10 Aug. 2006), and Michael H. Nelson. 2006. "Thailands Wahlen vom Februar 2005: Thaksins kurzlebiger Triumph" (forthcoming in Internationales Asienforum; Engl. version “Thailand's 2005 General Election: Thaksin's Shortlived Triumph", unpublished manuscript).

[xxiii] A brief description of the work of his Thongbai Thongpao Foundation can be found in Kevin F. F. Quigley. 1996. "Towards Consolidating Democracy: The Paradoxical Role of Democracy Groups in Thailand." Democratization 3 (3): 264-286.

[xxiv] On 23 April, 26 seats were filled in by-elections in 17 provinces, most of them in the south. The ECT planned a second round of by-elections in 14 constituencies in nine southern provinces. It was anticipated that this second round would still leave eight seats unfilled, because only single TRT candidates were standing with slim chances of passing the 20 percent threshold (Bangkok Post, 25 April 2006).

[xxv] Quoted from an unofficial translation printed in The Nation (26 April 2006). All major Thai newspapers printed the King's speeches.

[xxvi] Unavoidably, the King's intervention raised the question of royal power and the constitution within the context of the particularities of Thai politics (similar to October 1973, October 1976, and May 1992). In an ideology-heavy five-part series of articles on royal power, staunch royalist-liberal Borwornsak Uwanno, just after he had resigned from his position as secretary-general of the Thaksin-cabinet, praised a foreign journalist for his correct understanding: "The writer made a sound conclusion that critics may allege that the palace has conspired to hold the ultimate reins of power in Thailand, but with His admonition of the judiciary to do their job, (His Majesty the King) has laid down a legacy of support for modern democracy in Thailand and that the King supports pluralism. (From the article 'When kings do good' by Michael Vatikiotis, International Herald Tribune, May 18, 2006, p.7.) This analysis shows that His Majesty the King upholds his role as a constitutional monarch by advising the constitutional organs to perform their duties, instead of asking the King to breach his constitutional duties" (Bangkok Post, 13 June 2006).

[xxvii] See the decision of the Constitutional Court as published on its website (Khamwinitchai thi 9/2549, 8 May 2549).

[Xxviii] In a polling station that I observed in Chachoengsao province, within 10 minutes I saw that four voters ticked the "no vote" box, which was placed on the right on the bottom of the ballot paper and could make a well-founded guess that another voter had ticked the TRT box placed near the top of the ballot on the left-hand side.

[xxix] One election commissioner had earlier died. His position was still vacant.

[xxx] At the time of writing, I have not yet finished my detailed reading of the court's verdict. So far, no analysis or criticism of the verdict has been published, although some newspapers printed the entire piece. This situation might have to do with the fact that most observers were happy with having the ECT punished, irrespective of the "legal details." However, there have been critical voices, too. They might have been impeded by the courts' handling of the contempt-of-court issue. Worachet Pakeerat, a 
German-trained associate professor of law at Thammasat University, indicated his criticism but added, "Though the court said academic comments could be made, I don't have the confidence [to make stronger comments]" (The Nation, 6 Aug. 2006).

[xxxi] For a list of the candidates see Bangkok Post (11 Aug. 2006).

[xxxii] The Thai word baramee is often translated as "charisma." This is not correct. A person has baramee when he can command many people to follow his requests for certain actions because he has built up a high level of respect over decades by his good deeds.

[xxxiii] See Bidhya Bowornwathana. 2004. "Thaksin's Model of Government Reform: Prime Ministerislisation through 'A Country Is My Company' Approach." Asian Journal of Political Science 12

(1): 135-153.

Michael H. Nelson is a visiting scholar at the Faculty of Political Science, Chulalongkorn University, Bangkok, Thailand; and a senior researcher at the Department of South East Asian Studies, University of Passau, Germany.

(C) 2006 eastasia.at 